\title{
Regulation of Follistatin Messenger Ribonucleic Acid Levels in the Rat Pituitary
}

Ursula B. Kaiser and William W. Chin

Division of Genetics, Department of Medicine, Brigham and Women's Hospital, Howard Hughes Medical Institute, and Harvard Medical School, Boston, Massachusetts 02115

\begin{abstract}
Follistatin is a glycoprotein, originally isolated from the gonads, that specifically inhibits follicle-stimulating hormone (FSH) biosynthesis and secretion. We have previously detected follistatin mRNA in rat pituitary gonadotropes. To assess the potential physiologic role of follistatin in the rat pituitary, we have investigated the effects of gonadectomy (GDX) and of sex steroid replacement on pituitary follistatin gene expression. Follistatin mRNA levels in individual rat pituitaries were measured by a quantitative reverse transcription-polymerase chain reaction assay. Female and male rats $21 \mathrm{~d}$ old underwent surgical GDX and were then killed $21 \mathrm{~d}$ after GDX. Follistatin mRNA levels in rat pituitary increased $3.2 \pm 1.5$-fold ( $P$ $<0.01)$ in GDX female rats and 8.2 \pm 2.0 -fold $(P<0.005)$ in GDX male rats, compared with intact female and male controls, respectively. Replacement therapy with $17 \beta$-estradiol-3-benzoate $(10 \mu \mathrm{g} / 100 \mathrm{~g}$ body weight) subcutaneously daily for $7 \mathrm{~d}$ in GDX female rats resulted in a slight further increase in follistatin mRNA levels compared to GDX females. In contrast, therapy with testosterone propionate $(500 \mu \mathrm{g} / 100 \mathrm{~g}$ body weight ) subcutaneously daily for $7 \mathrm{~d}$ in GDX male rats resulted in a decrease in follistatin mRNA levels, towards but not completely back to baseline levels in intact males. Time-course studies in adult male and female rats showed that the increase in follistatin mRNA levels after GDX is rapid, with significant increases occurring within $24 \mathrm{~h}$ after GDX, and parallels or precedes increases in FSH $\beta$ mRNA levels and FSH secretion. The regulation of follistatin mRNA levels in the rat pituitary by GDX and by sex steroids suggests that follistatin may be important as an autocrine or paracrine factor in the regulation of FSH. (J. Clin. Invest. 1993. 91:2523-2531.) Key words: androgens $\bullet$ estrogen $\bullet$ follicle-stimulating hormone $\bullet$ follistatin • gonadotropins $\bullet$ polymerase chain reaction
\end{abstract}

\section{Introduction}

The regulation of the biosynthesis and secretion of the gonadotropins, follicle-stimulating hormone (FSH) ${ }^{1}$ and luteinizing

Address reprint requests to Dr. Kaiser, Room 909, G. W. Thorn Research Building, Brigham and Women's Hospital, 20 Shattuck Street, Boston, MA 02115.

Received for publication 23 September 1992 and in revised form 5 January 1993.

1. Abbreviations used in this paper: CAST, castration; $\mathrm{E}_{2}, 17 \beta-$ estradiol-3-benzoate; FSH, follicle-stimulating hormone; GDX, gonadectomy; GnRH, gonadotropin-releasing hormone; LH, luteinizing hormone; OVX, ovariectomy; RT, reverse transcription; T, testosterone propionate.

J. Clin. Invest.

(c) The American Society for Clinical Investigation, Inc.

$0021-9738 / 93 / 06 / 2523 / 09 \quad \$ 2.00$

Volume 91, June 1993, 2523-2531 hormone (LH), is critical for normal reproductive function (1). The synthesis and release of these two pituitary hormones are controlled by the complex interactions of multiple factors, including hypothalamic gonadotropin-releasing hormone ( GnRH) and gonadal steroids (2). In addition, a number of peptides have recently been identified that specifically influence FSH biosynthesis and secretion and thus contribute to differential regulation of FSH and $\mathrm{LH}$ during the estrous or menstrual cycle. These include inhibins, activins, and follistatin (3-5).

Inhibins and activins are structurally related proteins belonging to a family of growth and differentiation factors that includes TGF $\beta(6)$. These peptides were originally isolated from ovarian follicular fluid, but the inhibin/activin subunits and their messenger ribonucleic acids (mRNAs) have subsequently been detected not only in the ovaries and testes, but also in many extragonadal tissues, including the pituitary (7). Inhibin decreases, whereas activin increases FSH $\beta$ mRNA levels, cell content, and secretion $(8,9)$. Treatment of cultured rat anterior pituitary cells with a monoclonal antibody specific for activin B suppresses basal FSH secretion (10), which suggests that activin $B$ may be produced locally in the pituitary and may serve as an autocrine or paracrine signal in the regulation of FSH biosynthesis and secretion.

Follistatin, like inhibins and activins, was originally isolated and purified from ovarian follicular fluid (11-13). Although its effects are similar to those of inhibin, it is structurally distinct. Follistatin is a monomeric glycoprotein that suppresses the basal cell content and release of FSH in rat pituitary cells in vitro $(14,15)$ as well as inhibiting the synthesis and secretion of FSH induced by activin and $\operatorname{GnRH}(8,16)$. No effects of follistatin on LH synthesis or secretion have been shown. Similar effects of follistatin have been demonstrated on ovariectomized rats in vivo (17). Follistatin mRNA has been detected in a wide variety of extragonadal tissues, including the kidney, cerebral cortex, and decidual tissue (18-20). In addition, we and others have detected follistatin mRNA in the rat pituitary (20-23). The synthesis of follistatin by the pituitary suggests that follistatin, like activin $\mathrm{B}$, may have an autocrine or paracrine role in the regulation of FSH biosynthesis and secretion. It has been shown that follistatin is able to bind activin, and it has been postulated that the effects of follistatin on FSH synthesis and secretion may be mediated indirectly by binding to and thereby modulating the effects of activin (23-25).

To begin to assess the potential physiological importance of follistatin as an autocrine or paracrine factor in the regulation of FSH in the rat pituitary, we studied the effects of endocrine manipulations that are known to modulate FSH biosynthesis and secretion on follistatin gene expression in the pituitary. We have developed a quantitative reverse transcription (RT)-PCR assay to allow the quantitation of follistatin mRNA levels in individual rat pituitary total RNA samples. In this study, we have investigated the regulation of pituitary follistatin gene expression by gonadectomy (GDX) and by sex steroid replace- 
ment in gonadectomized rats. Our results indicate that follistatin mRNA levels in the pituitary are increased by gonadectomy in both male and female rats. However, differential effects of estrogen and androgen replacement of gonadectomized rats are observed. Estrogen replacement in ovariectomized female rats causes a further increase in pituitary follistatin mRNA levels. In contrast, testosterone replacement in orchiectomized male rats causes a decrease in pituitary follistatin mRNA levels.

\section{Methods}

\section{Experimental protocols}

Adult (200-225 g) and 21-d-old female and male Sprague-Dawley rats (CD strain; Charles River Breeding Laboratories, Wilmington, MA) were used in all experiments. All animals were killed by decapitation and trunk blood was collected for serum FSH and LH determinations. Pituitary glands were removed by dissection and quick-frozen on dry ice.

Protocol for ribonuclease ( $R$ Nase) protection analysis experiments. 20 male and 20 female rats at $21 \mathrm{~d}$ of age underwent surgical GDX by orchiectomy (castration, CAST) and ovariectomy (OVX), respectively. The GDX animals were killed $21 \mathrm{~d}$ after CAST or OVX. Intact adult male and female rats were used as controls.

Protocol for quantitative RT-PCR assay experiments. These experiments were performed with 21 -d-old male and both 21 -d-old and adult female rats. Rats underwent GDX as described above. The GDX animals were divided into two groups. In the first group, animals were killed $21 \mathrm{~d}$ after CAST or OVX. In the second group, rats $21 \mathrm{~d}$ postGDX received daily subcutaneous injections with sex steroid hormones. Females were injected with $17 \beta$-estradiol-3-benzoate $\left(E_{2}, 10\right.$ $\mu \mathrm{g} / 100 \mathrm{~g}$ body weight per day) and males were injected with testosterone propionate ( $\mathrm{T}, 500 \mu \mathrm{g} / 100 \mathrm{~g}$ body weight per day) in sesame oil. Animals were killed $7 \mathrm{~d}$ after the initial injections. Four rats were included in each group.

Time course protocol. Adult male and female rats underwent GDX as described above. The GDX animals were again divided into two groups. In the first group, animals were killed $1,3,7,14$, or $21 \mathrm{~d}$ after CAST or OVX. In the second group, rats $21 \mathrm{~d}$ post-GDX received daily subcutaneous injections with sex steroid hormones as described above. Animals were killed $8 \mathrm{~h}$ or 1,2 , or $7 \mathrm{~d}$ after injections were initiated. Control rats were treated with sesame oil only for $7 \mathrm{~d}$. Three to seven rats were studied for each group.

\section{Preparation of RNA}

Total RNA was prepared by homogenization of individual rat pituitaries in $4 \mathrm{M}$ guanidinium thiocyanate and centrifugation through $5.7 \mathrm{M}$ $\mathrm{CsCl}$ (26). The RNA concentration was estimated by measuring the $A_{260}$.

\section{RNase protection analysis}

Poly A(+) RNA was prepared from $500 \mu \mathrm{g}$ of total pituitary RNA from intact and GDX female and male rats, using oligo ( $\mathrm{dT}$ ) columns (Pharmacia, Inc., Piscataway, NJ). These RNA samples, as well as $20 \mu \mathrm{g}$ of total RNA from mature rat ovaries, rat kidney, and rat liver were submitted to RNase protection analysis using a specific rat follistatin antisense RNA probe, as described previously (21). The detection of a protected fragment of follistatin mRNA that is 168 nucleotides in length was predicted. A DNA sequence ladder was used as molecular size markers. Autoradiography was performed on X-ray film (Eastman Kodak Co., Rochester, NY) with an intensifying screen at $-70^{\circ} \mathrm{C}$ for $18 \mathrm{~h}$.

\section{Quantitative RT-PCR assay}

Oligonucleotide primers were designed based on the sequence of rat follistatin such that the expected product would be 337 basepairs in length, as described previously (21). A competitive template was generated by subcloning a 42-basepair random sequence oligonucleotide into an Xbal site within the 337-basepair fragment. This competitive template could thus be amplified by PCR by the same primers to generate a 379-basepair product. The developed protocol is modified from that described by Gilliland et al. (27) and was performed as follows. 2 $\mu \mathrm{g}$ of total RNA from each rat pituitary was reversed transcribed at $37^{\circ} \mathrm{C}$ for $1 \mathrm{~h}$ using an oligo $(\mathrm{dT})_{12-18}$ primer (Pharmacia, Inc.) in a total volume of $20 \mu \mathrm{l}$. Each reaction mixture included $1 \times$ PCR buffer ( 50 $\mathrm{mM} \mathrm{KCl}, 10 \mathrm{mM}$ Tris- $\mathrm{HCl}$ [ $\mathrm{pH} 8.3$ ] $, 1.5 \mathrm{mM} \mathrm{MgCl} 2,0.01 \%$ [wt/vol] gelatin), $4 \mu \mathrm{l}$ of $2.5 \mathrm{mM}$ deoxyribonucleotides, $40 \mathrm{pmol}$ of oligo(dT) 12-18 $_{18}$ primer, $1 \mathrm{mM}$ dithiothreitol, $20 \mathrm{U}$ of RNasin (Promega Corp., Madison, WI), and $40 \mathrm{U}$ of SuperScript RNase H-minus reverse transcriptase (Life Technologies, Inc., Gaithersburg, MD). After the incubation was completed, the reaction mixtures were boiled for 10 min. $1 \mu \mathrm{l}$ of each reaction mixture was used as a template for subsequent PCR amplification of rat follistatin. Each PCR sample included $5 \mu \mathrm{l}$ of $2.5 \mathrm{mM}$ deoxyribonucleotides, $45 \mathrm{pmol}$ of each primer, $1 \mathrm{U}$ of Taq polymerase (Perkin-Elmer Cetus, Norwalk, CT), $1 \mu$ l of RT reaction mixture, $1.5 \mu \mathrm{Ci}$ of $\left[\alpha^{32} \mathrm{P}\right] \mathrm{dCTP}$, and $1 \times$ PCR buffer to a final volume of $100 \mu \mathrm{l}$ were added, and the sample was overlaid with mineral oil. A series of four to five PCR reaction mixtures were set up for each $\mathrm{RT}$ reaction sample; competitive template DNA of known concentration from a dilution series was then added to each, such that follistatin cDNA generated by RT from total pituitary RNA would be co-amplified with a known amount of competitive template DNA. Amplification was carried out for 30 cycles, denaturing at $94^{\circ} \mathrm{C}$ for $1 \mathrm{~min}$, annealing at $51^{\circ} \mathrm{C}$ for $1 \mathrm{~min}$, and extending at $72^{\circ} \mathrm{C}$ for $3 \mathrm{~min}$. Control samples for each RNA from which reverse transcriptase had been omitted were run in parallel. $15 \mu$ l of each PCR sample was subjected to electrophoresis on a $4 \%$ polyacrylamide gel for analysis of amplification results. The gels were then dried and subjected to autoradiography. Bands corresponding to follistatin cDNA and competitive template DNA were quantitated by laser densitometry (Molecular Dynamics, Sunnyvale, CA) and their ratios were calculated.

\section{Subunit mRNA determinations}

$5 \mu \mathrm{g}$ of total RNA $\left(A_{260}\right)$ from each sample was denatured and subjected to electrophoresis and diffusion blotting onto Duralon membrane (Stratagene, Inc., La Jolla, CA) (28). Each blot was hybridized successively with $\mathrm{FSH} \beta$ and $\mathrm{LH} \beta$ cDNA probes, using conditions previously described $(29,30)$. Blots were washed and subjected to autoradiography, and band densities were determined by laser densitometry (Molecular Dynamics).

\section{RIA of FSH and $L H$}

Serum levels of rat FSH and $\mathrm{LH}$ were determined by RIAs using reagents from the National Institute of Arthritis, Metabolism, and Digestive Diseases (Bethesda, MD), as described previously (30,31), except that RP-2 standards were used for the FSH RIA, and RP-3 standards were used for the LH RIA. The FSH assay had a sensitivity of 190 $\mathrm{pg} / \mathrm{ml}$, an interassay variability of $7.9 \%$, and an intraassay variability of $10.7 \%$. The $\mathrm{LH}$ assay had a sensitivity of $54 \mathrm{pg} / \mathrm{ml}$, an interassay variability of $12.0 \%$, and an intraassay variability of $10.9 \%$.

\section{Standardization of data}

The total amounts of RNA in each sample were internally standardized by determining the level of $18 \mathrm{~S}$ RNA for each sample by laser densitometry of negative image photographs of Northern blots and correcting the follistatin, $\mathrm{FSH} \beta$, and $\mathrm{LH} \beta$ mRNA levels accordingly (32).

\section{Statistical analysis}

A $t$ test for independent samples was used to assess the statistical significance of changes in follistatin, $\mathrm{FSH} \beta$, and $\mathrm{LH} \beta$ mRNA levels and changes in serum FSH and LH levels. 


\section{Results}

\section{RNase protection assay}

Male and female rats underwent GDX at the age of $21 \mathrm{~d}$, and animals were killed and pituitaries were isolated at $21 \mathrm{~d}$ postGDX. Intact adult male and female rats were used as controls. Poly A(+) RNA was prepared from $500 \mu \mathrm{g}$ of total pituitary RNA from each group of rats. These RNA samples, as well as $20 \mu \mathrm{g}$ of total RNA from rat ovaries, kidney, and liver, were hybridized with a specific rat follistatin riboprobe and subjected to ribonuclease digestion. Protected fragments were analyzed by denaturing polyacrylamide gel electrophoresis, followed by autoradiography. A protected fragment of the expected size ( 168 nucleotides) was seen in all pituitary RNA samples (Fig. 1), corresponding to that detected previously (21). Follistatin mRNA levels were increased by GDX in both female and male rat pituitaries compared to levels in intact female and male rat pituitaries, respectively. A protected fragment of the same size was seen in rat ovary and kidney RNA, used as positive controls. No protected fragments were detected in rat liver RNA, used as a negative control.

We wanted to confirm these results and to study this phenomenon further by examining the effects of sex steroid replacement of GDX rats on pituitary follistatin gene expression. However, RNase protection analysis was of limited utility as a method for these studies because of the prohibitively large amounts of pituitary RNA required to detect follistatin mRNA reliably. Therefore, we developed a quantitative RT-PCR assay.

\section{Quantitative RT-PCR assay}

In all subsequent experiments to assess follistatin mRNA levels in the rat pituitary, the quantitative RT-PCR assay was used. Total RNA from individual rat pituitaries was prepared, followed by RT using an oligo(dT) $)_{12-18}$ primer to generate cDNAs for use as templates for PCR amplification. Amplification by PCR was performed using two specific rat follistatin primers, producing an easily detected amplification product of the expected size (21). In order to quantitate the amplified product and to control for the efficiency of PCR amplification, a competitive template was added to all PCR reactions. This template was coamplified by the same primers used to amplify

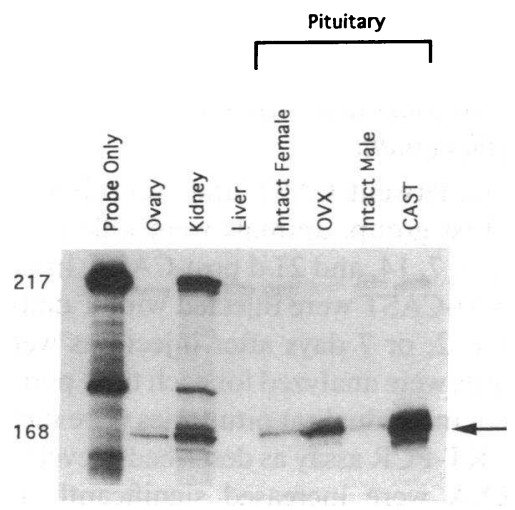

Figure 1. Follistatin mRNA levels in the rat pituitary as determined by ribonuclease protection analysis. Poly $\mathrm{A}(+)$ RNA prepared from $500 \mu \mathrm{g}$ of total rat pituitary RNA from intact and 21-d post-GDX female and male rats, and $20 \mu \mathrm{g}$ of total RNA from rat ovary, kidney, and liver, were hybridized with a specific rat follistatin antisense probe, subjected to ribonuclease digestion, and analyzed by denaturing PAGE followed by autoradiography. The protected fragment is indicated by the arrow on the right. The molecular sizes of the probe and the protected fragment, as derived from comparison with a DNA sequencing ladder, are indicated on the left. follistatin, but was modified by the insertion of a random oligonucleotide to generate a product of a slightly larger size. For each target cDNA sample generated by RT from a rat pituitary RNA sample, a series of PCR reactions was performed, such that follistatin cDNA was coamplified with a dilution series of competitor DNA of known concentration (for example, see Fig. 2). Polyacrylamide gel electrophoresis of the PCR amplification products followed by autoradiography and densitometric analysis allowed the amplified products of the follistatin cDNA and the competitive template to be distinguished and quantitated. The ratio of the products was then used to determine the concentration of follistatin cDNA generated from the pituitary RNA sample. The relative amounts of follistatin mRNA in individual rat pituitary samples could thus be compared.

As a negative control, corresponding RNA samples from each rat pituitary were treated identically except for the omission of reverse transcriptase. These samples resulted in no or minimal detectable amplification products, ruling out any significant contamination of RNA samples with genomic DNA, follistatin cDNA, or competitive template (data not shown).

\section{GDX and sex steroid replacement}

Male and female rats underwent GDX at the age of $21 \mathrm{~d}$ and were divided into two groups. The first group was killed $21 \mathrm{~d}$ after GDX. In the second group, male rats $21 \mathrm{~d}$ post-CAST were injected with $T$, and females with $E_{2}$, for $7 \mathrm{~d}$ before being killed. Four rats were included in each group. Follistatin mRNA levels in individual rat pituitaries were measured by the quantitative RT-PCR assay as described above. In male rats, follistatin mRNA levels were increased $8.2 \pm 2.0$-fold $(P$ $<0.005) 21 \mathrm{~d}$ after GDX compared to intact male controls (Fig. $3 \mathrm{~A}$ ). Similarly, in female rats, pituitary follistatin mRNA levels were also increased $21 \mathrm{~d}$ post-OVX compared to intact

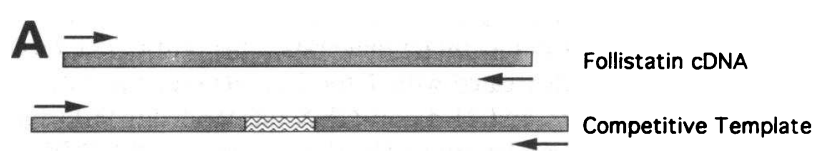

B

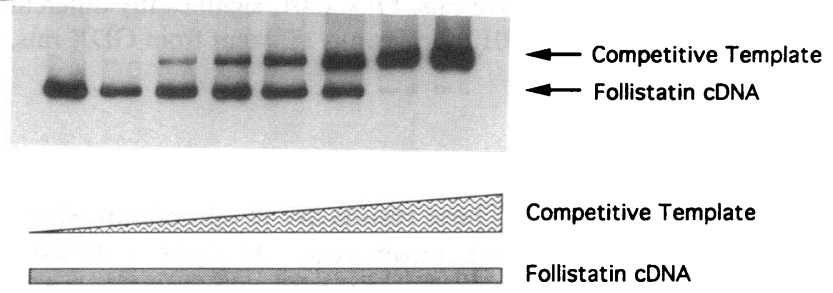

Figure 2. Use of a competitive template for the quantitation of follistatin cDNA. $(A)$ Schematic representation of the amplified 337-basepair portion of follistatin cDNA and of the competitive template. The hatched bar in the competitive template represents a 42-basepair random sequence oligonucleotide subcloned into an $\mathrm{XbaI}$ site within the 337-basepair fragment. The competitive template thus generates a 379-basepair fragment when amplified by PCR by the same primers. The arrows represent primers used for PCR amplification. (B) A titration curve derived from a series of PCR reactions containing a fixed amount of follistatin cDNA (derived from reverse-transcribed rat pituitary RNA) and progressively increasing amounts of competitive template DNA. The reactions were amplified and subjected to electrophoresis as described in Methods. 


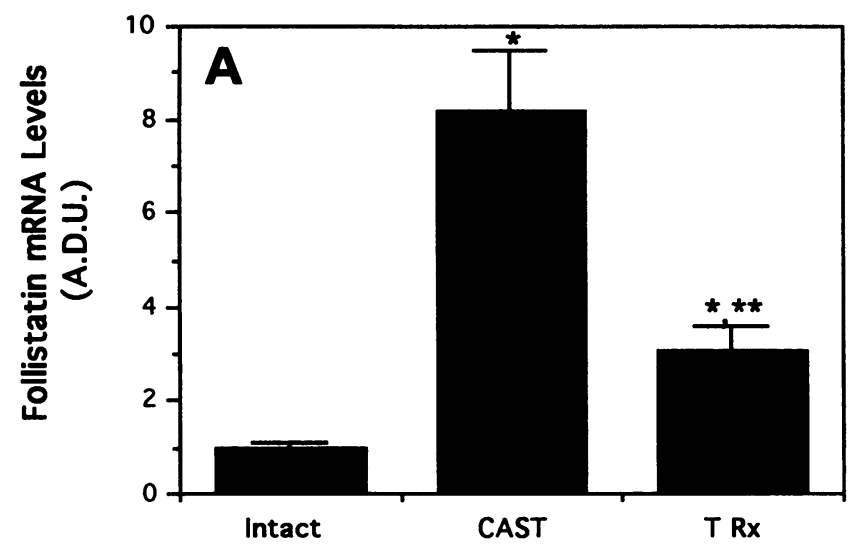

Table I. Pituitary FSH $\beta / L H \beta$ mRNA Levels and Serum FSH/LH Levels after Gonadectomy and after Sex Steroid Replacement in Male and Female Rats

\begin{tabular}{|c|c|c|c|c|}
\hline & \multicolumn{2}{|c|}{ Pituitary mRNA } & \multicolumn{2}{|c|}{ Serum } \\
\hline & $\mathrm{FSH} \beta$ & LH $\beta$ & FSH & LH \\
\hline & A.D.U. & A.D.U. & $n g / m l$ & $n g / m l$ \\
\hline \multicolumn{5}{|l|}{ Male } \\
\hline Intact & $1.0 \pm 0.2$ & $1.0 \pm 0.2$ & $22.0 \pm 1.5$ & $1.0 \pm 0.2$ \\
\hline CAST & $4.0 \pm 0.4^{*}$ & $2.9 \pm 0.2^{*}$ & $53.5 \pm 3.9^{*}$ & $7.8 \pm 0.3^{*}$ \\
\hline $\mathbf{T} \mathbf{R x}$ & $3.5 \pm 0.5^{\ddagger}$ & $0.6 \pm 0.1^{\S}$ & $31.6 \pm 1.9^{11}$ & $0.4 \pm 0.1^{\S}$ \\
\hline \multicolumn{5}{|l|}{ Female } \\
\hline Intact & $1.0 \pm 0.4$ & $1.0 \pm 0.2$ & $11.0 \pm 1.3$ & $0.4 \pm 0.1$ \\
\hline ovX & $13.6 \pm 1.8^{\prime}$ & $3.1 \pm 0.6^{* *}$ & $55.8 \pm 3.6^{1}$ & $8.8 \pm 0.7^{1}$ \\
\hline$E_{2} R x$ & $1.2 \pm 0.5^{\ddagger \ddagger}$ & $0.7 \pm 0.2^{\S \S}$ & $27.9 \pm 1.5^{\ddagger \ddagger}$ & $1.7 \pm 0.1^{\ddagger \ddagger}$ \\
\hline
\end{tabular}

All data are expressed as mean $\pm \operatorname{SEM}(n=4)$. A.D.U., arbitrary densitometric units. ${ }^{*} P<0.0005$ compared with intact males. ${ }^{\ddagger} P$ $=$ NS compared with CAST males. ${ }^{\$} P<0.0005$ compared with CAST males. " $P<0.005$ compared with CAST males. ' $P<0.0005$ compared with intact females. ${ }^{* *} P<0.005$ compared with intact females. ${ }^{\ddagger} P<0.005$ compared with OVX females. ${ }^{\$} P<0.025$ compared with OVX females.

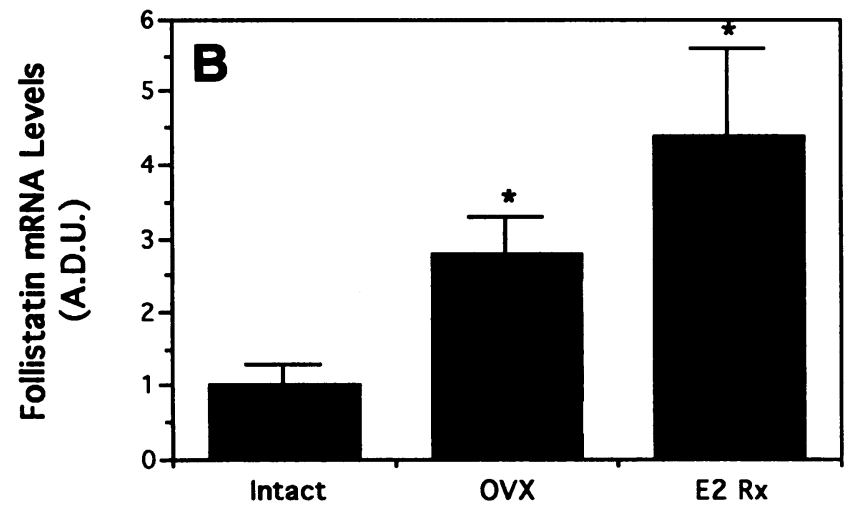

Figure 3. Changes in rat pituitary follistatin mRNA levels after gonadectomy and sex steroid replacement. Quantitation of pituitary follistatin mRNA levels in $(A)$ intact male rats, $21-\mathrm{d}$ post-CAST rats, and $21-\mathrm{d}$ post-CAST rats treated with $\mathrm{T}$ for $7 \mathrm{~d} ;(B)$ intact female rats, $21-\mathrm{d}$ post-OVX rats, and 21-d post-OVX rats treated with $E_{2}$ for $7 \mathrm{~d}$. Levels of mRNA were determined by the quantitative RT-PCR assay as described in Methods. mRNA levels are expressed as arbitrary densitometric units $(A . D . U$. $)$. Each bar represents the mean \pm SEM for three to five rats. ${ }^{*} P<0.01$, significantly different from intact rats; ${ }^{* *} P<0.01$, significantly different from GDX rats.

females, although to a lesser extent, increasing by $3.2 \pm 1.5$-fold $(P<0.01)$ (Fig. $3 B)$. These results are in agreement with the results of the RNase protection assay. Analysis of follistatin mRNA levels in the pituitaries of CAST male rats treated with $\mathrm{T}$ for $7 \mathrm{~d}$ revealed a decrease of $2.9 \pm 1.0$-fold $(P<0.01)$ when compared to CAST males; however, levels were still $3.2 \pm 0.8$ fold $(P<0.005)$ above those in intact male rats. In contrast, pituitary follistatin mRNA levels did not decrease in OVX female rats in response to $7 \mathrm{~d}$ of treatment with $\mathrm{E}_{2}$; in fact, levels tended to increase somewhat, although the increase did not reach statistical significance.

As shown in Table $\mathrm{I}$, in male rats, pituitary LH $\beta$ mRNA levels and serum LH levels increased appropriately in response to CAST, and decreased appropriately in response to $T$ therapy (29). Pituitary FSH $\beta$ mRNA levels increased after GDX, but did not change significantly in response to $T$ replacement, in

agreement with previous reports $(30,33)$. Serum FSH levels increased after GDX, then decreased somewhat after T replacement, but did not return entirely to baseline levels seen in intact male rats, again in agreement with previous reports (30). In female rats, pituitary $\mathrm{FSH} \beta$ and $\mathrm{LH} \beta$ mRNA levels, and serum FSH and LH levels, increased appropriately after OVX, and decreased appropriately in response to $E_{2}$ replacement $(29$, $30,33)$.

The same experimental paradigm was repeated using adult female rats. Adult female rats were OVX and were divided into two groups. The first group was killed $21 \mathrm{~d}$ after GDX. In the second group, female rats 21 days post-GDX were injected with $E_{2}$ for $7 d$ before killing. Four rats were included in each group. Follistatin mRNA levels in individual rat pituitaries were measured by the quantitative RT-PCR assay. Changes in pituitary follistatin mRNA levels were almost identical to those seen in 21-d-old female rats, as were changes in pituitary FSH $\beta$ and LH $\beta$ mRNA levels and serum FSH and LH (data not shown).

\section{Time course of changes in follistatin $m R N A$ levels after} GDX and sex steroid replacement

Males. Adult male rats underwent CAST and were divided into two groups. In the first group, animals were killed and pituitaries were isolated $1,3,7,14$, and $21 \mathrm{~d}$ post-CAST. In the second group, rats $21 \mathrm{~d}$ post-CAST were injected with $\mathrm{T}$ daily, and animals were killed 1, 2, or 7 days after injections were initiated. Three to seven rats were analyzed for each time point. Follistatin mRNA levels in individual rat pituitaries were measured by the quantitative RT-PCR assay as described. Levels of pituitary follistatin mRNA were increased significantly $(P$ $<0.005$ ) by $24 \mathrm{~h}$ post-CAST, the earliest time point examined (Fig. 4). Levels continued to increase progressively with time, and were increased $20.6 \pm 5.8$-fold $(P<0.0005)$ over levels in intact adult male rats by $21 \mathrm{~d}$ post-CAST. Replacement with $\mathrm{T}$ resulted in a prompt decrease in pituitary follistatin mRNA 


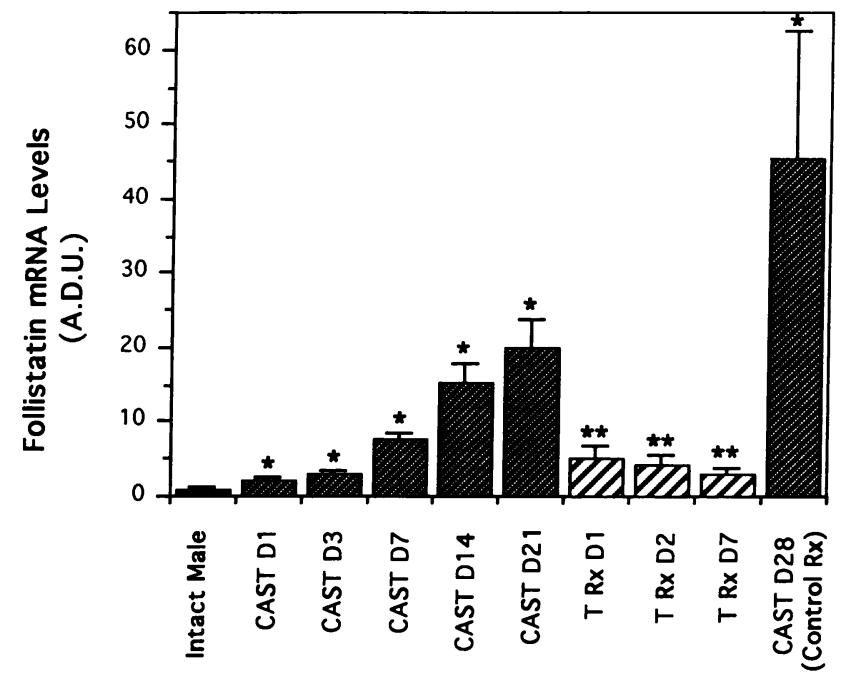

Figure 4. Time course of changes in pituitary follistatin mRNA levels following CAST and T replacement in male rats. Quantitation of pituitary follistatin mRNA levels at various time points after CAST, and at various time points after treatment with $\mathrm{T}$. Control-treated rats were $21-d$ post-CAST rats treated with sesame oil only for $7 \mathrm{~d}$. Levels of mRNA were determined by the quantitative RT-PCR assay as described in Methods. mRNA levels are expressed as arbitrary densitometric units (A.D.U.). Each bar represents the mean \pm SEM for three to seven rats. ${ }^{*} P<0.01$, significantly different from intact male rats; ${ }^{* *} P<0.005$, significantly different from $21-\mathrm{d}$ post-CAST rats.

levels, with a decrease of $4.2 \pm 1.8$-fold $(P<0.005)$, compared to levels in 21-d post-CAST male rats, by $24 \mathrm{~h}$ after T replacement was initiated, the earliest time point examined. Levels decreased further with longer $\mathrm{T}$ therapy, and were reduced by $7.1 \pm 2.8$-fold $(P<0.0005)$, compared to levels in $21-\mathrm{d}$ postCAST male rats, after $7 \mathrm{~d}$ of $\mathrm{T}$ replacement. Follistatin mRNA levels in control rats, $21 \mathrm{~d}$ post-CAST and treated for $7 \mathrm{~d}$ with daily sesame oil injections, did not decrease, but, in fact, continued to increase further.

Pituitary LH $\beta$ mRNA and serum LH levels increased promptly after CAST, and decreased acutely in response to $\mathrm{T}$ replacement, returning to baseline levels seen in intact adult male rats. Pituitary FSH $\beta$ and serum FSH levels also increased after CAST; however, the increase was more gradual and less marked than the changes seen in LH. Levels did decrease somewhat with $\mathrm{T}$ replacement, but again more gradually than $\mathrm{LH}$, and levels did not return to baseline values (data not shown).

Females. Similar studies were performed in females. Adult female rats underwent surgical OVX and were divided into two groups. In the first group, rats were sacrificed and pituitaries were isolated $1,3,7,14$, or $21 \mathrm{~d}$ post-OVX. In the second group, adult female rats $21 \mathrm{~d}$ post-OVX were given daily subcutaneous injections with $\mathrm{E}_{2}$ and were killed $8 \mathrm{~h}$ or 1,2 , or $7 \mathrm{~d}$ after injections were initiated. Four to seven rats were analyzed for each time point. Follistatin mRNA levels in individual rat pituitaries were measured by the quantitative RT-PCR assay as described. Levels of pituitary follistatin mRNA were increased significantly $(P<0.0005)$ by $24 \mathrm{~h}$ post-OVX, the earliest time point examined (Fig. 5). Interestingly, levels then decreased somewhat at 3 and $7 \mathrm{~d}$ post-OVX, before increasing further at 14 and $21 \mathrm{~d}$ post-OVX, reaching a maximum level of a

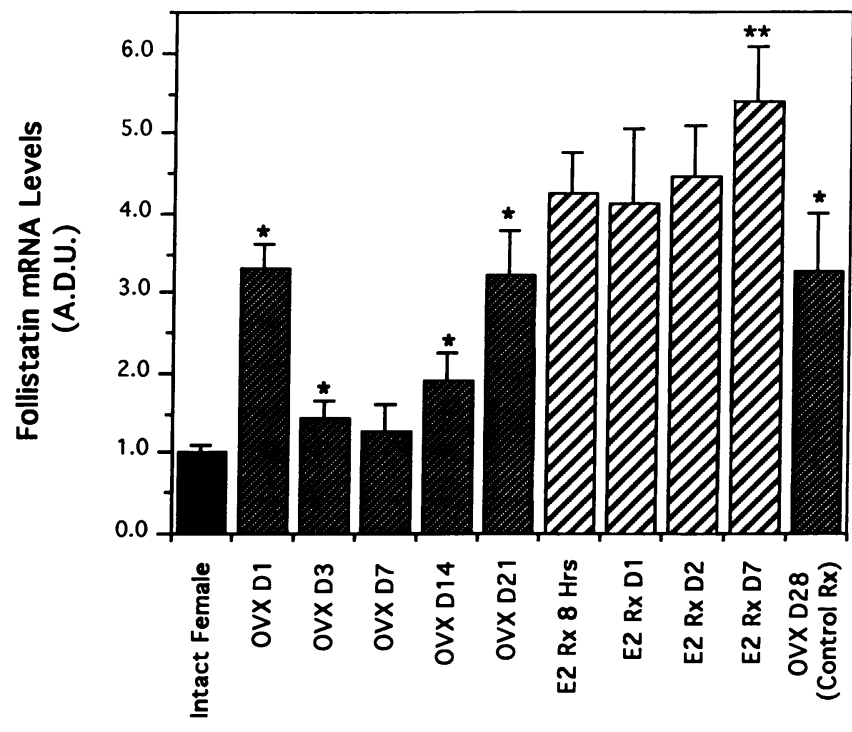

Figure 5. Time-course of changes in pituitary follistatin mRNA levels after OVX and $E_{2}$ replacement in female rats. Quantitation of pituitary follistatin mRNA levels at various time points after OVX, and at various time points after treatment with $\mathrm{E}_{2}$. Control-treated rats were $21-\mathrm{d}$ post-OVX rats treated with sesame oil only for $7 \mathrm{~d}$. Levels of mRNA were determined by the quantitative RT-PCR assay as described in Methods. mRNA levels are expressed as arbitrary densitometric units (A.D.U.). Each bar represents the mean \pm SEM for four to seven rats. ${ }^{*} P<0.025$, significantly different from intact female rats; ${ }^{* *} P<0.025$, significantly different from 21 -d post-OVX rats.

$3.4 \pm 0.8$-fold increase $(P<0.0005)$ over baseline levels in intact adult female rats. In contrast to $T$ replacement in CAST male rats, replacement with $E_{2}$ in 21 -d post-OVX females did not result in a decrease in pituitary follistatin mRNA levels, but, in fact, caused a slight and gradual increase in levels, reaching statistical significance after $7 \mathrm{~d}$ of $\mathrm{E}_{2}$ replacement, at which time pituitary follistatin mRNA levels were increased by $1.8 \pm 0.4$-fold $(P<0.025)$ compared to levels in $21-\mathrm{d}$ OVX rats. Follistatin mRNA levels in control rats, $21 \mathrm{~d}$ post-OVX and treated for $7 \mathrm{~d}$ with daily sesame oil injections, were unchanged compared to levels in $21-\mathrm{d}$ post-OVX rats.

Pituitary LH $\beta$ mRNA and serum LH levels increased appropriately after OVX, and decreased appropriately in response to $E_{2}$ replacement, returning towards but not entirely back to baseline levels seen in intact adult female rats. Pituitary FSH $\beta$ and serum FSH levels increased progressively after OVX to a maximum $21 \mathrm{~d}$ post-OVX. Levels decreased progressively with $E_{2}$ replacement, towards but not entirely back to baseline values (data not shown).

\section{Discussion}

This study examines the regulation of follistatin gene expression in the rat pituitary. The presence of follistatin in the rat pituitary has been documented previously (20-23), but the physiologic importance of follistatin as a potential autocrine or paracrine factor in the regulation of FSH biosynthesis and secretion is not known. The regulation of follistatin gene expression in the rat pituitary by GDX and by gonadal steroid replacement, which also modulate FSH biosynthesis and secretion, suggests that the local production of follistatin in the rat pitu- 
itary may have important physiological consequences in the regulation of the hypothalamic-pituitary-gonadal axis.

The regulation of the biosynthesis and secretion of FSH and LH has been well characterized in female and male rats after GDX and after replacement with estrogen and testosterone $(29,30)$, and therefore this provides a good animal model in which to study the regulation of pituitary follistatin gene expression. The doses of $E_{2}$ and $T$ administered in this study were chosen because they are supraphysiologic and the responses of FSH and LH at both the pre- and posttranslational levels have been well characterized previously $(29,30,33,34)$. However, in view of the supraphysiological doses of $E_{2}$ and $T$ used in these replacement experiments, the data should be interpreted with care regarding their physiological implications.

RNase protection analysis was initially used as an assay to quantitate the levels of follistatin mRNA present in the rat pituitary under the different experimental conditions. This method gave a reproducible signal of the expected size and showed an increase in the signal after GDX in both male and female rats, reflecting an increase in follistatin mRNA levels. However, RNase protection analysis required the use of large amounts of total pituitary RNA to detect and quantitate the follistatin mRNA signal reliably, and was therefore impractical as a method to study the regulation of pituitary follistatin gene expression in more detail. We therefore developed a quantitative RT-PCR assay.

In the quantitative RT-PCR assay, mRNA was first converted to cDNA, and follistatin cDNA was then amplified using specific oligonucleotide primers. This assay is extremely sensitive due to the exponential nature of the amplification (35); therefore, much smaller quantities of RNA could be used, allowing the detection of follistatin mRNA in RNA samples from individual rat pituitaries. The inclusion of a competitive template DNA allowed accurate quantitation of follistatin cDNA, and hence of follistatin mRNA (27). Amplification of both follistatin cDNA and its competitive template used the same primers and therefore all variables which affect the efficiency of amplification would affect both products equally. Accordingly, the ratio of follistatin cDNA product to competitor product should remain constant throughout the amplification process, and the ratio of these amplified products should precisely reflect the initial concentration of follistatin cDNA versus the concentration of the added competitive template.

Initial studies comparing the levels of follistatin mRNA in the pituitaries of intact and GDX rats by the quantitative RTPCR assay showed an increase in pituitary follistatin mRNA levels in both female and male rats after GDX. These results are in agreement with the results of the RNase protection assay, thus confirming the increase in pituitary follistatin gene expression following GDX and validating the quantitative RT-PCR assay as a means for quantitating follistatin mRNA levels in individual rat pituitary samples. The increase in follistatin gene expression in both female and male rats after GDX, a procedure which also causes an increase in FSH biosynthesis and secretion, suggests that the local production of follistatin in the rat pituitary may have important physiologic consequences.

The mechanism(s) of action of follistatin in the pituitary. remains speculative at this point. It is known that follistatin is an activin-binding protein (23-25), and it has been shown in the pituitary and other tissues that follistatin can interfere with the actions of activin $(8,36-38)$. One possible mechanism of action, therefore, is that follistatin binds to activin in the pituitary, derived either from local production or from the circulation, and thereby prevents the binding of activin to its receptor, resulting in the inhibition of FSH synthesis and secretion (Fig. $6 \mathrm{~A}$ ). However, based on this model, we would predict that follistatin gene expression in the pituitary should decrease in response to GDX, resulting in a decrease in activin binding by follistatin, allowing more free activin to act on gonadotropes to stimulate FSH biosynthesis, and contributing to the increase in FSH levels that occurs after GDX. To reconcile the increase in follistatin mRNA levels which occurs after GDX with this model, one could speculate that the increase in follistatin occurs only in response to the rising FSH levels, and serves to inhibit an even greater or excessive rise in FSH biosynthesis after GDX. However, follistatin mRNA levels increased promptly after GDX, and the rise in follistatin paralleled or even preceded the increase in FSH $\beta$ mRNA levels, making this possibility less likely.

An alternative mechanism of action of follistatin may be invoked to account for the increase of follistatin gene expression that occurs after GDX (Fig. $6 \mathrm{~B}$ ). It has recently been shown that follistatin associates with the cell surface of follicular granulosa cells by binding to heparan sulfate side chains of membrane-bound proteoglycans (39). It is possible that similar proteoglycans are present in the pituitary, and that follistatin produced locally in the pituitary is bound by these proteoglycans. Such cell-associated follistatin may bind to activin in the extracellular environment and mediate the interaction of activin with its receptor, either by trapping and maintaining activin in the vicinity of the cell surface, by prolonging the half-life of activin, or by increasing the affinity of activin for its receptor. This would result in an increased stimulation of FSH biosynthesis and secretion by activin in the presence of increased local follistatin, as occurs after GDX.

The activin-follistatin-proteoglycan interaction can be compared to the interactions of the structurally related protein, TGF- $\beta$, with its receptors and binding proteins. TGF- $\beta$ binds to four distinct cell-surface proteins with high affinity and specificity (for review, see reference 40). Type I receptor is a glycoprotein and appears to be primarily responsible for signal transduction. Type II receptor is also a glycoprotein, and, like the activin receptor, is a transmembrane serine/threonine kinase (41). Type IV receptor has thus far been detected only in a pituitary tumor cell line and is unique in its ability to crossreact with activin and inhibin (42). Type III receptor, however, is the most abundant cell surface receptor for TGF- $\beta$ and is a proteoglycan (43-45). Forms of this proteoglycan that lack the membrane anchor are present in extracellular matrices. The role of this proteoglycan is not clear, but it has been postulated to be involved in the presentation of TGF- $\beta$ to the type I or type II signal transduction receptor, or to act as a reservoir or clearance system for TGF- $\beta$.

Other mechanisms of action of follistatin are also possible. Follistatin may have direct effects on gonadotropes to modulate FSH biosynthesis or secretion. Alternatively, follistatin may act indirectly by modulating the effects of GnRH or other factors on gonadotropes.

In OVX female rats, treatment with $\mathrm{E}_{2}$ did not reverse the increase in follistatin mRNA levels seen after OVX. In fact, follistatin mRNA levels increased after $\mathrm{E}_{2}$ treatment compared to vehicle-treated control animals. These results suggest that $E_{2}$ 


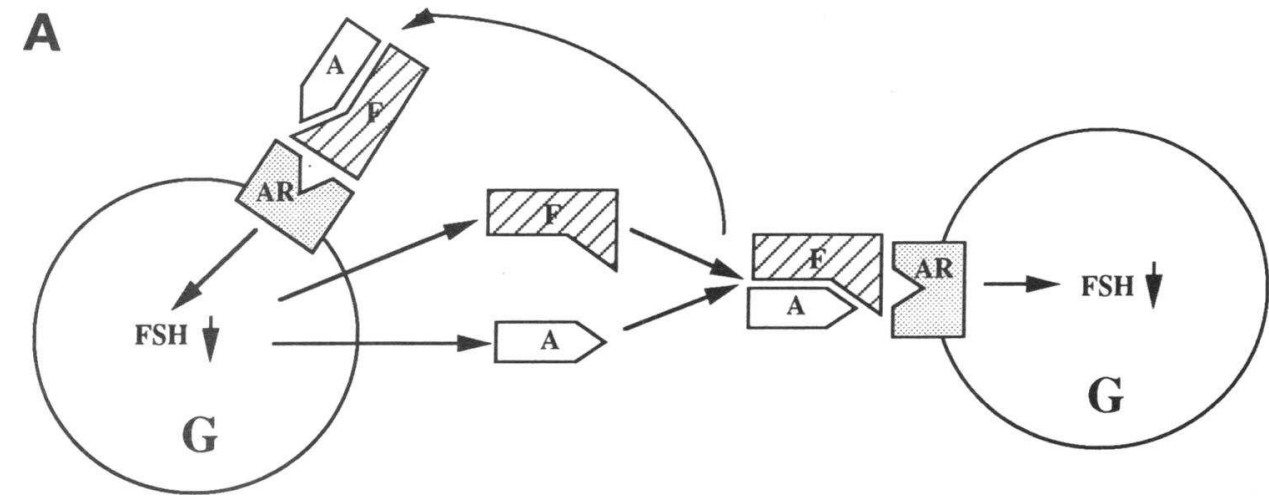

B

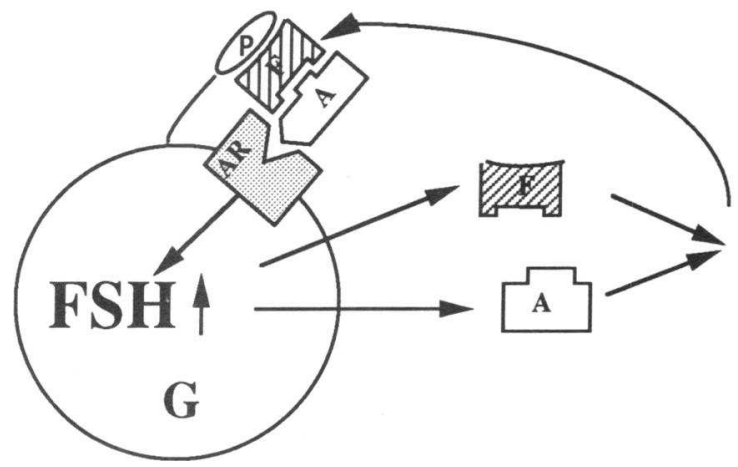

Figure 6. Schematic representation of possible autocrine/paracrine mechanisms of action of follistatin in the regulation of FSH synthesis and secretion. $(A)$ Follistatin produced locally in the pituitary may bind to activin, derived either from local production or from the circulation, thus preventing the interaction of activin with its receptor on the surface of gonadotropes, resulting in the inhibition of FSH synthesis and secretion. $(B)$ Follistatin produced locally in the pituitary may associate with membranebound proteoglycans, bind to activin in the extracellular environment, and mediate the interaction of activin with its receptor, resulting in the stimulation of FSH synthesis and secretion. $A$, activin; $F$, follistatin; $A R$, activin receptor; $P$, proteoglycan; $F S H$, follicle-stimulating hormone; $G$, gonadotrope. does not inhibit follistatin gene expression, but may have a weak stimulatory effect. The increase in follistatin mRNA levels seen after OVX is therefore not due to the reduction in circulating estrogen. One must postulate that there is some other ovarian factor(s) that inhibits pituitary follistatin gene expression, directly or indirectly, such that OVX removes this inhibitory effect and allows follistatin mRNA levels to increase. One possible candidate for this inhibitory factor is inhibin, which is known to be produced in the ovary and to be an important factor involved in the inhibition of FSH synthesis and secretion (3-5). The biphasic response of levels of pituitary follistatin mRNA after OVX (a rapid rise within $24 \mathrm{~h}$ after OVX, followed by a decrease at 3 and $7 \mathrm{~d}$ post-OVX, before increasing further at 14 and $21 \mathrm{~d}$ post-OVX) supports our suggestion that multiple factors are involved in the regulation of pituitary follistatin gene expression. At this point, we can only speculate on possible mechanisms to account for this pattern. For example, it is possible that the removal of an inhibitory gonadal factor(s) such as inhibin causes the rapid increase in follistatin mRNA seen at $24 \mathrm{~h}$ post-OVX. Subsequent changes in levels of pituitary follistatin mRNA may then be due to the interactions of several other direct and indirect effects of OVX, such as the removal of other ovarian factors, changes in hypothalamic function such as GnRH pulse amplitude and frequency, as well as changes in other putative pituitary paracrine factors. Further studies both in vivo and in vitro are necessary to identify the mediators of the changes in pituitary follistatin mRNA levels after OVX and after $E_{2}$ replacement.
In contrast, in GDX male rats, treatment with $\mathrm{T}$ caused a decrease in pituitary follistatin mRNA levels. This decrease was rapid, and follistatin mRNA levels were significantly reduced by $24 \mathrm{~h}$ after $\mathrm{T}$ treatment was initiated, which was the earliest time point examined. Follistatin levels returned towards but not entirely back to baseline levels seen in intact male rats after $7 \mathrm{~d}$ of treatment with $\mathrm{T}$. The increase in follistatin gene expression in male rats after CAST may therefore be due, at least in part, to the removal of inhibitory effects of testosterone produced and secreted by the testis. However, there may be another inhibitory factor(s) produced by the testis that also contributes to the increase in pituitary follistatin after CAST. This would account for the failure of follistatin mRNA levels to return to baseline after treatment with $T$. One can again speculate that this second inhibitory factor present in the testis is inhibin. Further studies are necessary to test this hypothesis. The presence of at least two putative follistatin-inhibitory factors in the testis versus a possible single putative inhibitory factor in the ovary may explain why the increase in follistatin mRNA levels following GDX was greater in male rats versus female rats.

The differential regulation of follistatin mRNA levels by estrogen and androgen is particularly interesting because it implicates follistatin as a possible mediator of the sexually dimorphic regulation of FSH which occurs in the rat. FSH $\beta$ mRNA levels are negatively regulated by $E_{2}$ in vivo $(30,33)$. In contrast, FSH $\beta$ mRNA levels are less sensitive to negative regulation by $\mathrm{T}$ in vivo $(30,33)$. Furthermore, differential effects of estrogen and androgen occur directly at the level of the pitu- 
itary. In primary rat pituitary cultures, testosterone stimulates FSH $\beta$ mRNA levels, whereas estrogen has no effect (46). In view of the differential effects of estrogen and testosterone on pituitary follistatin as well as on $\mathrm{FSH} \beta$ mRNA levels, it is possible that follistatin is involved in mediating the effects of estrogen and androgen on FSH.

In conclusion, GDX results in an increase in follistatin mRNA levels in the pituitaries of both female and male rats that parallels or precedes the increase in FSH biosynthesis and secretion. $\mathrm{E}_{2}$ replacement in $\mathrm{OVX}$ female rats does not reverse this increase, but, in fact, stimulates a further increase in pituitary follistatin mRNA levels. In contrast, $T$ replacement in CAST male rats causes a decrease in pituitary follistatin mRNA levels. The regulation of follistatin gene expression in the rat pituitary by gonadectomy and by sex steroid replacement suggests the local production of follistatin in the rat pituitary may have important physiological consequences. In order to understand fully the regulation of the hypothalamic-pituitary-gonadal axis, the roles of inhibin, activin, and follistatin as endocrine and/or paracrine factors need to be further elucidated.

\section{Acknowledgments}

We thank Barbara Ernisse for her assistance with FSH and LH RIAs. Reagents for the RIAs were provided by the National Institute of Diabetes and Digestive and Kidney Disease (NIDDK) and the National Hormone and Pituitary Program (University of Maryland School of Medicine).

This work was supported, in part, by National Institutes of Health grant HD-19938 to Dr. Chin and a Medical Research Council of Canada Clinician-Scientist Award to Dr. Kaiser.

\section{References}

1. Pierce, J. G., and T. F. Parsons. 1981. Glycoprotein hormones: structure and function. Annu. Rev. Biochem. 50:465-495.

2. Fink, G. 1979. Feedback action of target hormones on hypothalamus and pituitary with special reference to gonadal steroids. Annu. Rev. Physiol. 41:571585.

3. Vale, W., A. Hsueh, C. Rivier, and J. Yu. 1990. The inhibin/activin family of hormones and growth factors. In Handbook of Experimental Pharmacology, Vol. 95, Peptide Growth Factors and Their Receptors II. M. B. Sporn and A. B. Roberts, editors. Springer-Verlag, Inc., New York, 211-248.

4. Ying, S.-Y. 1988. Inhibins, activins, and follistatin: gonadal proteins modulating the secretion of follicle-stimulating hormone. Endocr. Rev. 9:267-293.

5. Attardi, B., J. Vaughan, and W. Vale. 1992. Regulation of FSH $\beta$ messenger ribonucleic acid levels in the rat by endogenous inhibin. Endocrinology. 130:557559.

6. Massague, J. 1987. The TGF- $\beta$ family of growth and differentiation factors. Cell. 49:437-438.

7. Meunier, H., C. Rivier, R. M. Evans, and W. Vale. 1988. Gonadal and extragonadal expression of inhibin $\alpha, \beta \mathrm{A}$, and $\beta \mathrm{B}$ subunits in various tissues predicts diverse functions. Proc. Natl. Acad. Sci. USA. 85:247-251.

8. Carroll, R. S., A. Z. Corrigan, S. D. Gharib, W. Vale, and W. W. Chin. 1989. Inhibin, activin and follistatin: regulation of follicle-stimulating hormone messenger ribonucleic acid levels. Mol. Endocrinol. 3:1969-1976.

9. Attardi, B., H. S. Keeping, S. J. Winters, F. Kotsuji, R. A. Maurer, and P. Troen. 1989. Rapid and profound suppression of messenger ribonucleic acid encoding follicle-stimulating hormone $\beta$ by inhibin from primate Sertoli cells. Mol. Endocrinol. 3:280-287.

10. Corrigan, A. Z., L. M. Bilezikjian, R. S. Carroll, L. N. Bald, C. H Schmelzer, B. M. Fendly, A. J. Mason, W. W. Chin, R. H. Schwall, and W. Vale 1991. Evidence for an autocrine role of activin B within rat anterior pituitary cultures. Endocrinology. 128:1682-1684.

11. Ueno, N., N. Ling, S.-Y. Ying, F. Esch, S. Shimasaki, and R. Guillemin 1987. Isolation and partial characterization of follistatin: a single-chain $M_{r} 35,000$ monomeric protein that inhibits the release of follicle-stimulating hormone. Proc. Natl. Acad. Sci. USA. 84:8282-8286.
12. Robertson, D. M., R. Klein, F. L. de Vos, R. I. McLachlin, R. E. H. Wettenhall, M. T. W. Hearn, H. G. Burger, and D. M. de Kretser. 1987. The isolation of polypeptides with FSH suppressing activity from bovine follicular fluid which are structurally different to inhibin. Biochem. Biophys. Res. Commun. 149:744-749.

13. Esch, F. S., S. Shimasaki, M. Mercado, K. Cooksey, N. Ling, S. Ying, N. Ueno, and R. Guillemin. 1987. Structural characterization of follistatin: a novel follicle-stimulating hormone release-inhibiting polypeptide from the gonad. $\mathrm{Mol}$. Endocrinol. 1:849-855.

14. Ying, S.-Y., A. Becker, G. Swanson, P. Tan, N. Ling, F. Esch, N. Ueno, S. Shimasaki, and R. Guillemin. 1987. Follistatin specifically inhibits pituitary follicle stimulating hormone release in vitro. Biochem. Biophys. Res. Commun. 149:133-139.

15. Robertson, D. M., P. G. Farnworth, L. Clarke, J. Jacobsen, N. F. Cahir, H. G. Burger, and D. M. de Kretser. 1990. Effects of bovine 35 kDa FSH-suppressing protein on FSH and LH in rat pituitary cells in vitro: comparison with bovine $31 \mathrm{kDa}$ inhibin. J. Endocrinol. 124:417-423.

16. Wang, Q. F., P. G. Farnworth, J. K. Findlay, and H. G. Burger. 1990. Chronic inhibitory effect of follicle-stimulating hormone (FSH)-suppressing protein (FSP) or follistatin on activin- and gonadotropin-releasing hormone-stimulated FSH synthesis and secretion in cultured rat anterior pituitary cells. Endocrinology. 127:1385-1393.

17. DePaolo, L. V., M. Shimonaka, R. H. Schwall, and N. Ling. 1991. In vivo comparison of the follicle-stimulating hormone-suppressing activity of follistatin and inhibin in ovariectomized rats. Endocrinology. 128:668-674.

18. Shimasaki, S., M. Koga, M. L. Buscaglia, D. M. Simmons, T. A. Bicsak, and N. Ling. 1989. Follistatin gene expression in the ovary and extragonadal tissues. Mol. Endocrinol. 3:651-659.

19. Kaiser, M., G. Gibori, and K. E. Mayo. 1990. The rat follistatin gene is highly expressed in decidual tissue. Endocrinology. 126:2768-2770.

20. Michel, U., A. Albiston, and J. K. Findlay. 1990. Rat follistatin: gonada and extragonadal expression and evidence for alternative splicing. Biochem. Biophys. Res. Commun. 173:401-407.

1. Kaiser, U. B., B. L. Lee, R. S. Carroll, G. Unabia, W. W. Chin, and G. V. Childs. 1992. Follistatin gene expression in the pituitary: localization in gonadotropes and folliculostellate cells in diestrous rats. Endocrinology. 130:3048-3056.

22. Gospodarowicz, D., and K. Lau. 1989. Pituitary follicular cells secrete both vascular endothelial growth factor and follistatin. Biochem. Biophys. Res. Commun. 165:292-298.

23. Kogawa, K., T. Nakamura, K. Sugino, K. Takio, K. Titani, and H. Sugino. 1991. Activin-binding protein is present in pituitary. Endocrinology. 128:1434-1440.

24. Nakamura, T., K. Takio, Y. Eto, H. Shibai, K. Titani, and H. Sugino. 1990. Activin-binding protein from rat ovary is follistatin. Science (Wash. DC). 247:836-838.

25. Shimonaka, M., S. Inouye, S. Shimasaki, and N. Ling. 1991. Follistatin binds to both activin and inhibin through the common beta-subunit. Endocrinology. 128:3313-3315.

26. Chirgwin, J. M., A. E. Przybyla, R. J. MacDonald, and W. J. Rutter. 1979. Isolation of biologically active ribonucleic acid from sources enriched with ribonuclease. Biochemistry. 18:5294-5299.

27. Gilliland, G., S. Perrin, K. Blanchard, and H. F. Bunn. 1990. Analysis of cytokine mRNA and DNA: detection and quantitation by competitive polymerase chain reaction. Proc. Natl. Acad. Sci. USA. 87:2725-2729.

28. Thomas, P. S. 1980. Hybridization of denatured RNA and small DNA fragments transferred to nitrocellulose. Proc. Natl. Acad. Sci. USA. 77:52015205

29. Gharib, S. D., S. M. Bowers, L. R. Need, and W. W. Chin. 1986. Regulation of rat luteinizing hormone subunit messenger ribonucleic acids by gonada steroid hormones. J. Clin. Invest. 77:582-589.

30. Gharib, S. D., M. E. Wierman, T. M. Badger, and W. W. Chin. 1987. Sex steroid hormone regulation of follicle-stimulating hormone subunit messenger ribonucleic acid (mRNA) levels in the rat. J. Clin. Invest. 80:294-299.

31. Badger, T. M., C. E. Wilcox, E. R. Meyer, R. D. Bell, and T. J. Cicero. 1978. Simultaneous changes in tissue and serum levels of luteinizing hormone follicle-stimulating hormone, and luteinizing hormone / follicle-stimulating hormone releasing factor after castration in the male rat. Endocrinology. 102:136141.

32. Correa-Rotter R., C. N. Mariash, and M. E. Rosenberg. 1992. Loading and transfer control for Northern hybridization. Biotechniques. 12:154-158.

33. Wierman, M. E., S. D. Gharib, J. M. LaRovere, T. M. Badger, and W. W. Chin. 1988. Selective failure of androgens to regulate follicle-stimulating hormone $\beta$ messenger ribonucleic acid levels in the male rat. Mol. Endocrinol. 2:492-498.

34. Wierman, M. E., S. D. Gharib, C. Wang, J. M. LaRovere, T. M. Badger, and W. W. Chin. 1990. Divergent regulation of gonadotropin subunit mRNA levels by androgens in the female rat. Biol. Reprod. 43:191-195.

35. Saiki, R. K., D. H. Gelfand, S. Stoffel, S. J. Scharf, R. Higuchi, G. T. Horn, 
K. B. Mullis, and H. A. Erlich. 1988. Primer-directed enzymatic amplification of DNA with a thermostable DNA polymerase. Science (Wash. DC). 239:487-491.

36. Shiozaki, M., R. Sakai, M. Tabuchi, T. Nakamura, K. Sugino, H. Sugino, and Y. Eto. 1992. Evidence for the participation of endogenous activin A/erythroid differentiation factor in the regulation of erythropoiesis. Proc. Natl. Acad. Sci. USA. 89:1553-1556.

37. Shukovski, L., J. K. Findlay, and D. M. Robertson. 1991. The effect of follicle-stimulating hormone-suppressing protein or follistatin on luteinizing bovine granulosa cells in vitro and its antagonistic effect on the action of activin Endocrinology. 129:3395-3402.

38. Xiao, S., and J. K. Findlay. 1991. Interactions between activin and follicle-stimulating hormone-suppressing protein and their mechanisms of action on cultured rat granulosa cells. Mol. Cell. Endocrinol. 79:99-107.

39. Nakamura, T., K. Sugino, K. Titani, and H. Sugino. 1991. Follistatin, an activin-binding protein, associates with heparan sulfate chains of proteoglycans on follicular granulosa cells. J. Biol. Chem. 266:19432-1943.

40. Massague, J., S. Cheifetz, F. T. Boyd, and J. L. Andres. 1990. TGF- $\beta$ receptors and TGF- $\beta$ binding proteoglycans: recent progress in identifying their functional properties. Ann. N.Y. Acad. Sci. 593:59-72.
41. Lin, H. Y., X.-F. Wang, E. Ng-Eaton, R. A. Weinberg, and H. F. Lodish. 1992. Expression cloning of the TGF- $\beta$ type II receptor, a functional transmembrane serine/threonine kinase. Cell. 68:775-785.

42. Cheifetz, S., N. Ling, R. Guillemin, and J. Massague. 1988. A surface component on $\mathrm{GH}_{3}$ pituitary cells that recognizes transforming growth factor- $\beta$, activin, and inhibin. J. Biol. Chem. 263:17225-17228.

43. Andres, J. L., K. Stanley, S. Cheifetz, and J. Massague. 1989. Membraneanchored and soluble forms of betaglycan, a polymorphic proteoglycan that binds transforming growth factor- $\beta$. J. Cell Biol. 109:3137-3145.

44. Wang, X.-F., H. Y. Lin, E. Ng-Eaton, J. Downward, H. F. Lodish, and R. A. Weinberg. 1991. Expression cloning and characterization of the TGF- $\beta$ type III receptor. Cell. 67:797-805.

45. Lopez-Casillas, F., S. Cheifetz, J. Doody, J. Andres, W. S. Lane, and J. Massague. 1991. Structure and expression of the membrane proteoglycan betaglycan, a component of the TGF- $\beta$ receptor system. Cell. 67:785-795.

46. Gharib, S. D., P. C. K. Leung, R. S. Carroll, and W. W. Chin. 1990. Androgens positively regulate follicle-stimulating hormone $\beta$-subunit levels in rat pituitary cells. Mol. Endocrinol. 4:1620-1626. 